\title{
ASSESSING INADEQUATE URBAN INFRASTRUCTURE AND PLACE ATTACHMENT PERCEPTION AMONG RESIDENTS OF GATED SOCIETIES IN GREATER FARIDABAD, INDIA
}

\author{
Dr. Rashmi Rani Anand ${ }^{1}$ and Dr. Poonam Sharma ${ }^{2}$ \\ ${ }^{1}$ Assistant Professor, SBSC, University of Delhi \\ ${ }^{2}$ Associate Professor, SBSC, University of Delhi \\ DOI: 10.46609/IJSSER.2021.v06i02.014 URL: https://doi.org/10.46609/IJSSER.2021.v06i02.014
}

\begin{abstract}
Greater Faridabad is a semi urbanised part of National capital territory and parallel to Faridabad city. It has emerged as home of many high and midrise gated residential societies. For many people, gated societies in satellite towns appear to be a preferred option for residence. Migrants with high paying jobs also prefer living in the gated communities because of sense of community, prestige, lifestyle and security. The residential gated societies in these towns promise good living standards with various facilities and attract large population (Roitman, March, 2010). But on the other side as they are away from the city centre are not yet well endowed with basic urban facilities (The Hindu, 2014).Keeping pretext of various studies, which shows that lack of urban infrastructure impacts wellbeing, the present paper tries to understand residents' place attachment. The paper argues that place attachment in gated society is generally influenced by social groups and likeminded people, friends and neighbourhood. The study is largely based on the field work conducted in the study area in June, 2019. The methodology followed includes content analysis of news reports, review of relevant literature, transcriptions, analysis of secondary data as well as analysis of primary data collected through questionnaire from a sample of 50 respondents selected randomly from residential gated societies of greater Faridabad. Residence place attachment was then after statistically tested using simple logistic regressions and chi square. The findings of the survey suggest that the lack of accessibility of urban infrastructure in the study area makes people unsatisfied with respect to urban basic infrastructure, but is not the detrimental in developing place attachment, with the possible exception of "access to roads".
\end{abstract}

Keywords: Place Attachment, Urban Infrastructure, Greater Faridabad, Residential Gated Societies 


\section{International Journal of Social Science and Economic Research}

ISSN: $2455-8834$

Volume:06, Issue:02 "February 2021"

\section{Introduction}

Greater Faridabad which is semi urbanised, more and more people are pouring into the gated residential societies because of their better income and better living requirement (ThangavelPalanivel, 06 September 2017). For them gated societies appear to be most preferred option for residence because of sense of community, prestige, lifestyle and security. These residential societies accommodate a large number of these migrants(Ashwini M Sripad, 27th December, 2017).But on the other side as they are away from the city centre, they are not yet well endowed with basic urban facilities (The Hindu, 2014). Gated residential societies promise to provide a high quality, secure, clean and aesthetic existence for their inhabitants (IshaBhatnagar, March, 2017). They also provide social and emotional pride. Facilities, such as landscaped parks, gymnasium and play areas for children, within the premises of a gated society, when combined with advantageous geographical location can potentially enhance the sense of place attachment. However, delivering urban basic services to all efficiently and effectively in these residential societies is a great challenge (BijendraAhlawat, Sep 14, 2019).

Residents of Greater Faridabad, till date do not get to experience a full-fledged and functional infrastructure. Many gated societies face inadequate infrastructure like sewer disposal through tankers, heavy reliability on DG sets etc. causing inconvenience. Thus paper tries to unravel the relationship between urban infrastructure and place attachment for the residents of various gated societies of Greater Faridabad. Inadequate infrastructures and wellbeing of the people are the backbone for the development of cities and their liveability. Therefore, the paper tries to understand place attachment for the residents of gated societies of Greater Faridabad and influence of inadequate urban basic infrastructure on residents' place attachment.

\subsection{Place attachment and wellbeing}

Place attachment is a geographical and psychological construct that contributes to the feeling of "being at home". Additionally, it can provide a sense of trust and security and, potentially, support pro-environmental attitudes and behaviors (Noga Collins-Kreiner, 2020, Zening Song, Didier Soopramanien, 2019). Place attachment studies are important with respect to urban development and community building and enable us to understand influence of urban spaces on individuals' satisfaction as well as their attachment to a certain place (SoroushKarami, MojganGhafary, Abbas Fakhrayee , 2014). It has been argued that as it is a psychological process, it is greatly influenced by urban basic services, and that design of a city and infrastructure will influence individuals' place attachment (Dan Plunkett, $\underline{\text { Rhonda }}$

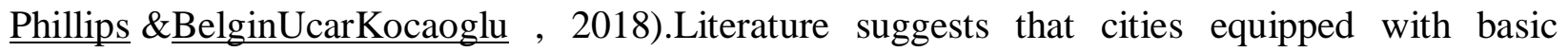
infrastructure give a decent quality of life, and clean and sustainable environment to its citizens. Further literature review on place attachment suggest divergent findings. 
International Journal of Social Science and Economic Research

ISSN: 2455-8834

Volume:06, Issue:02 "February 2021"

\subsection{Research Objectives}

The paper tries to investigate influence of inadequate urban infrastructure for gated residential societies and their sense of place attachment.

\subsection{Hypothesis}

The paper argues that place attachment in gated society is generally influenced by social groups and likeminded people, friends and neighbourhood. The state of urban infrastructure in satellite towns like Greater Faridabad makes people unsatisfied with respect to urban basic infrastructure but this is not detrimental in developing place attachment with the possible exception of "access to roads".

\subsection{Significance}

Understanding of place attachment is significant as it adds insight into the motivations of a resident's deep relationships with respect to their outer surrounding in any urban setup. Relph (1976) argues that personal experiences give meanings to places for an individual. Gated communities provide social sustainability (SamerBagaeen, Ola Uduku. 2010). The need of the hour is to focus on accommodating everyone coming to new emerging towns and ensuring infrastructure access for all. Wellbeing is an important aspect of the development process. Place attachment is also associated with physical and mental wellbeing, and people-place connection. A strong or positive place attachment creates a sense of rootedness, belonging, or an intense feeling of being at home."

\subsection{Limitation of the Study}

Variables chosen are Nominal and Ordinal. So any form of PARAMETRIC test not possible here.

\section{Material and Methods}

This is a broad, descriptive and comprehensive study based on both primary and secondary data. The required secondary data were collected through journals, books, industry reports, blogs, Facebook pages, twitter, newspaper articles, and other electronic sources. In order to collect the primary data, structured questionnaire on 5point Likert scale has been used. The study is also based on observation and collection of qualitative data. A rigorous twenty days' field work was conducted in June 2019 in Greater Faridabad various societies of Sector 84, 85 86, 87, 88, and 89. These sectors are primarily residential gated societies with middle and high income group people. 


\section{International Journal of Social Science and Economic Research}

ISSN: $2455-8834$

Volume:06, Issue:02 "February 2021"

The residents were selected from the residential societies of Greater Faridabad, without any subjective bias. The sampling units comprises of residents. The study was partly conducted online and partly through field visits. Structured and semi-structured interviews were conducted with RWA members and residents of various gated societies of Greater Faridabad. The analysis of adequacy of urban infrastructures was also done on the basis of newspaper content analysis covering local greater Faridabad news and resident's responses.

\subsection{Study Area}

Greater Faridabad is a satellite town of National capital territory and parallel to Faridabad city. It has emerged as home of many high and midrise gated societies. The area is also known as Naharpar area, and was conceptualised in 2004-05 in order to build mini township. Many families have migrated from Delhi and other neighbouring states for permanent residence. This sub-region has been developed as a sustainable city which has wide roads, tall buildings and entertainment zone with enough employment opportunities in industrial areas.

Greater Faridabad is situated at $28^{\circ} 25^{\prime} 16^{\prime \prime}$ north latitude and $77^{\circ} 18^{\prime} 28^{\prime \prime}$ east longitude. It is surrounded by National Capital Territory (NCT) Delhi on its North, in the West and South by Gurgaon District and Aravalli Hills. The river Yamuna separates the district boundary on eastern side with Uttar Pradesh State. Faridabad is the 9th biggest industrial estate of Asia. Its economy is primarily dependent on manufacturing units. Keeping in view that its population is expected to grow "The Haryana State Industrial and Infrastructure Development Corporation" has acquired land and developed an Industrial Modal Township (IMT) on the eastern side of the Agra Canal (Haryana Government Master Plan, 2031). The Neharpar area is primarily divided into residential sector and industrial sector. Industrial Sectors comprise of Sectors 66 to 74 while sectors 75 to 89 are Residential Sectors. Agra canal and Gurgaon canal passes through the length of the Greater Faridabad. The city has the merit of proximity to Delhi, as well as the National Capital Region cities of Greater Noida and Gurgaon. These factors are driving end users, investors and corporates to choose Greater Faridabad as a potential booming real estate destination (AkashVashistha, September 07, 2007). 
International Journal of Social Science and Economic Research

ISSN: 2455-8834

Volume:06, Issue:02 "February 2021"

\section{Map1: Location of Study Area: Greater Faridabad}

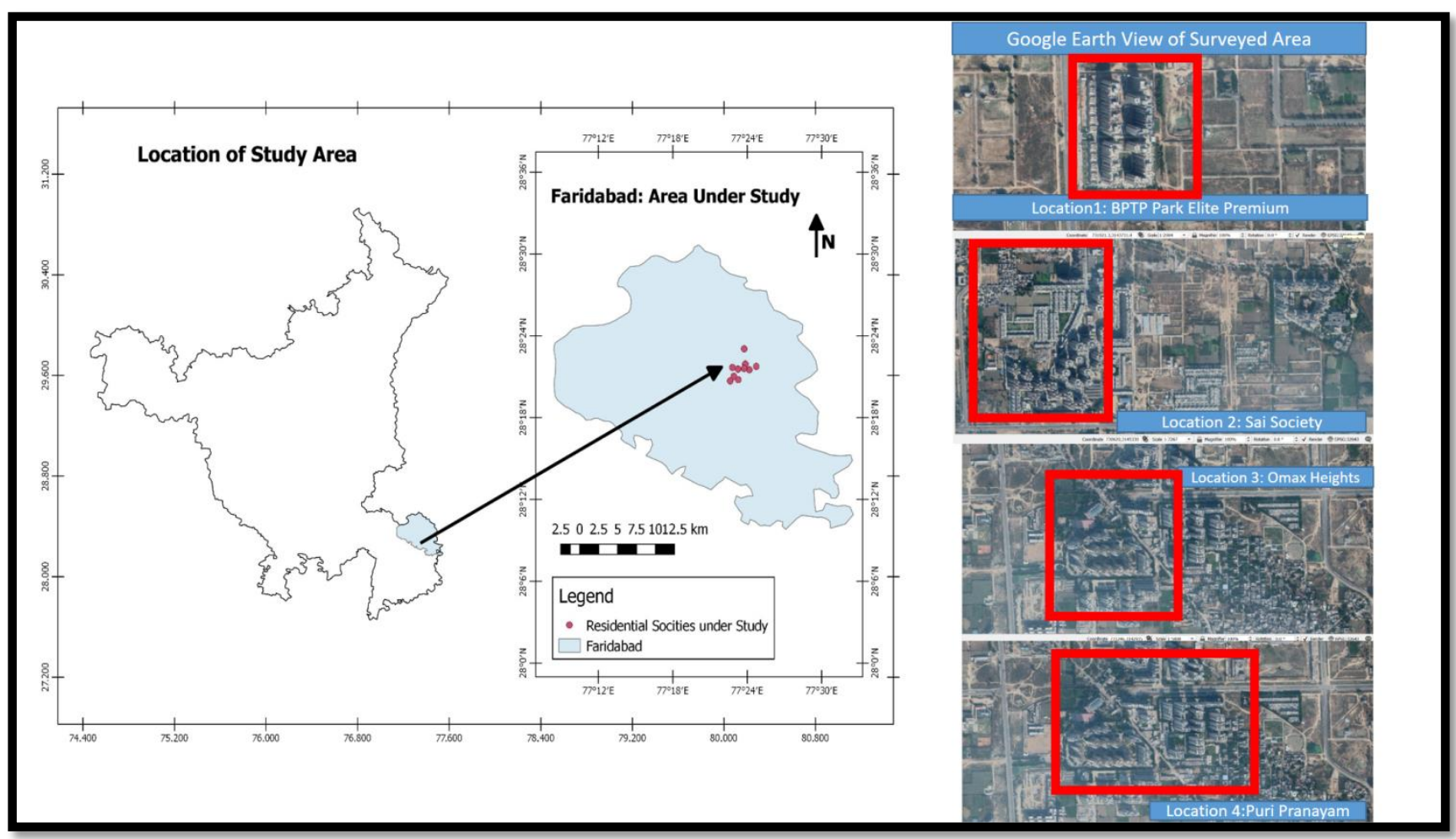

Source: Authors, 2020

The above illustration shows various gated societies of Greater Faridabad and have been taken from Google Earth Pro on 17 December 2020.

Location 1: BPTP Park Elite Premium and PuriPratham Society

Location 2: Sai Society

Location 3: Omax Heights Society

Location 4: PuriPranayam Society 
International Journal of Social Science and Economic Research

ISSN: 2455-8834

Volume:06, Issue:02 "February 2021"

Map 2: Land Use and Land Cover of Greater Faridabad

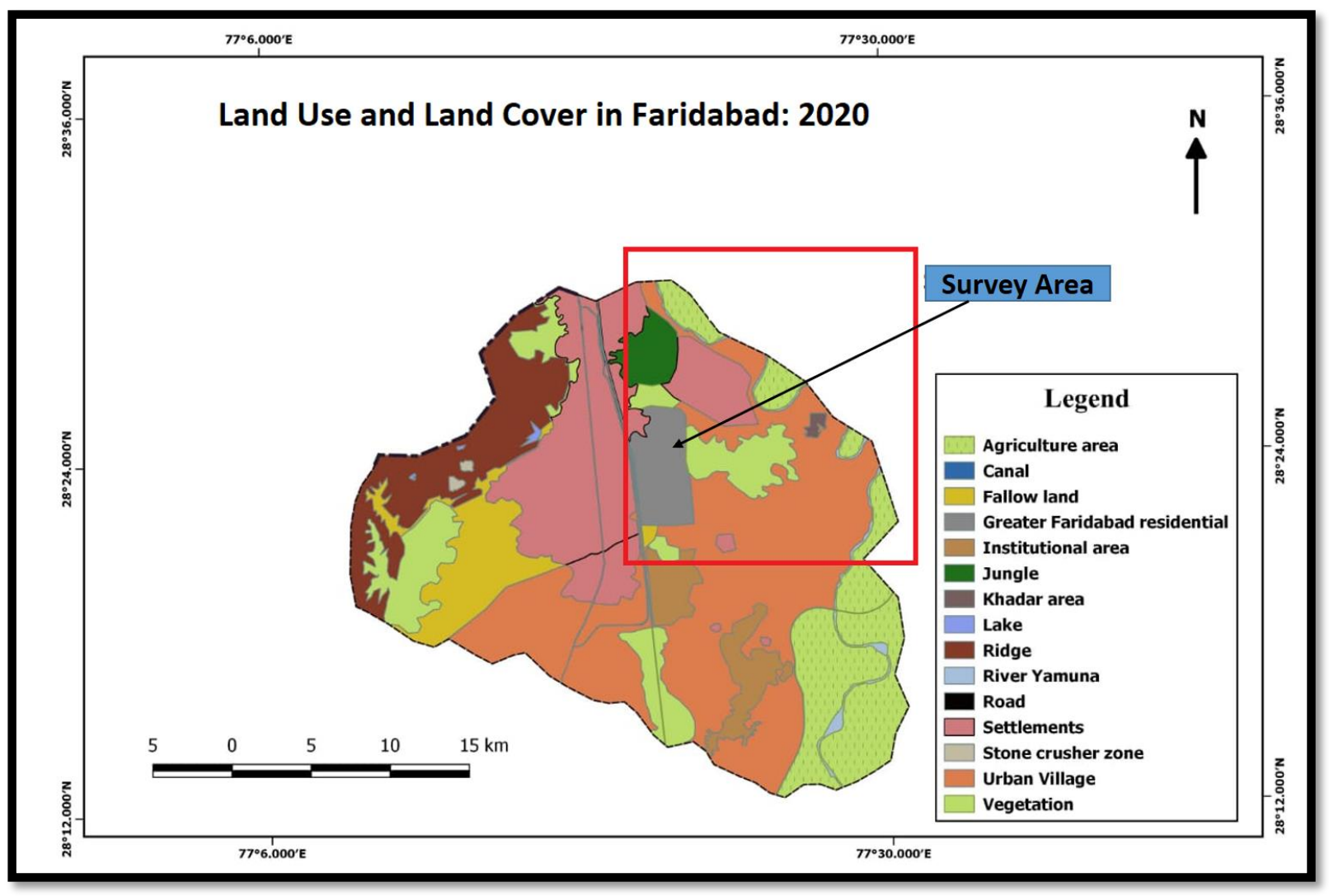

Source: Authors, 2020

The above map of Land use and Land cover of Faridabad was produced on the Landsat 8 satellite imagery with 30 metre resolution, for which was downloaded from USGS website on $14^{\text {th }}$ November, 2020.

\subsection{Questionnaire Design}

Review of literature on place attachment suggest that place attachment is multi-dimensional concept that refers to the emotional and affective bonds between a person and a place (Altman and Low, 1992). The availability of facilities inside and outside gated societies may have a different impact on place attachment. It can be measured in physical (forms and space) and social (emotional) dimension. Keeping that in mind questionnaire was developed to find any association between number of years stayed in the society and residents' place attachment and also tries measure whether different facilities impact the social place attachment of different groups of residents differently. 
The questionnaire was grouped into following sections:

\section{Satisfaction level in the residential society with respect to}

1. Infrastructure

2. Security system

3. access to road

4. sewer disposal in your society

5. cost of Power backup (DG)

6. access to public transport

7. traffic management

\section{Liking regarding}

8. Your neighbourhood

9. Place you live in

\section{Qualitative question:}

10. What you like about your society?

11. Do you feel attached to the place where you are living currently

12. For how long you have been living in the society (number of years)? Length of your stay.

13. Owner or at rent

14. Number of people in the household?

15. Do you have family/ friend network in the Greater Faridabad?

16. What is your satisfaction level regarding urban infrastructure quality in Greater Faridabad?

\subsubsection{Approach taken for Interviews, Discussions and Reviews}

The primary survey was conducted in June 2019; response was collected from 50 residents of various age groups. The respondent's male and female ratio was $50: 50$. The target population of the sample consist of mixture of age group starting from 25 to 60 and above.

The fieldwork consisted of participant observations and in-depth interviews conducted in informal settings. Participant observation, informal face to face interviews of different members 


\section{International Journal of Social Science and Economic Research}

ISSN: $2455-8834$

Volume:06, Issue:02 "February 2021"

of the gated societies were conducted. The conversations deliberately dealt with issues related to lack of infrastructure. Interviewees were also asked about their thoughts and experiences, their place attachment, and their sense of place.

Some of the questions were open-ended and they were analysed to capture qualitative analysis. Media analysis, blogs, on-line newspapers, and Facebook media pertaining to the issues were also analysed.

All the quantitative set of questions were measured on five-point scale. A Likert scale measured satisfaction level regarding inadequate urban infrastructure and pace attachment. The respondents used a 5-point scale with (1) meaning "not satisfied" and (5) meaning "very satisfied".

Residents' attachment of gated societies was statistically tested against accessibility of urban infrastructure outside residential societies, accessibility of infrastructure within residential societies and family and friends network within residential societies using simple logistic regressions. In logistic regression, chi square is used to test for the significance of the logistic regression model. The Model Chi-Square, also called Model L Square, is analogous to the Regression (explained) Sums of Squares (SSR), in Ordinary Least Squares (OLS) regression and a direct counterpart of the Global F test in OLS regression analysis. Place attachment was used as the dependent variable. Logistic regression was considered appropriate to test association since Place Attachment is a binary variable (Yes/No) variable. Standalone simple logistic regressions with each of the independent variables were performed because of sample size limitations.

\section{Results and Discussions}

The results achieved from the data analysis in the present research can be valuable for a real estate developer and municipal officials. The survey and interviews revealed that the residents were generally unsatisfied with the external urban basic infrastructure such as sanitation, powersupply, public transport and traffic management. Some of their comments on the state of infrastructure and urban amenities have been presented below:

1. "Except for Sector roads, there is nothing called infrastructure!"

2. "Deficiencies are there as Development Charges has been collected from individual flat buyers. Lacking in supply of water and electricity. There is absence of service road and proper sewerage system."

3. "Need market and transport facility."

4. "Not so good. Needs lot of improvement." 
5. "Not at all good. No drainage system. No sufficient power supply. Society has to give power through DG most of the time."

6. "...safety and maintenance issues."

7. "It's in really bad shape. Garbage everywhere on roads, open defecation..."

8. "Lack of urban infrastructure is a torture on the daily basis for the residents living in the society".

They appeared satisfied with internal facilities within their gated societies including the security system available within these societies. Moreover, a large proportion of the residents appeared to have developed place attachment, although they had been staying in greater Faridabad for less than five years in almost all cases with a few exceptions.

An analysis of the questionnaire responses is consistent with the findings of the group discussions and interviews. The insights drawn from these responses have been presented below.

\subsection{Satisfaction level among residents of Gated Societies with urban infrastructure quality in Greater Faridabad}

\subsubsection{Residents Satisfaction Level and Urban Infrastructure}

The provision of basic urban infrastructure is essential in any geographical setting and it is a very significant determinant of the quality of life of urban dwellers. Over the years, it has been known to tremendously serve the inhabitants of urban areas, thus it is often regarded as a prerequisite for the development of any urban economy. The significance of infrastructure in the proper functioning of an urban area cannot be overemphasised (R. A. Ogunbajo, M. O. Bello and M. A. Adebayo .June, 2016).

The lack of infrastructure in the Greater Faridabad is another important issue which requires much attention. The various issues and challenges regarding infrastructure were highlighted during the interview and the field visits. In the primary survey, 22 of 50 (44\%) respondents had a neutral opinion on the urban infrastructure quality in Greater Faridabad. Notably, 15 (30\%) were unsatisfied and $6(12 \%)$ were very unsatisfied. Only $7(14 \%)$ were satisfied or very satisfied. The full distribution of responses has been presented in the following graph. 
International Journal of Social Science and Economic Research

ISSN: 2455-8834

Volume:06, Issue:02 "February 2021"

\section{Graph 1: Urban Infrastructure Quality and Satisfaction Level}

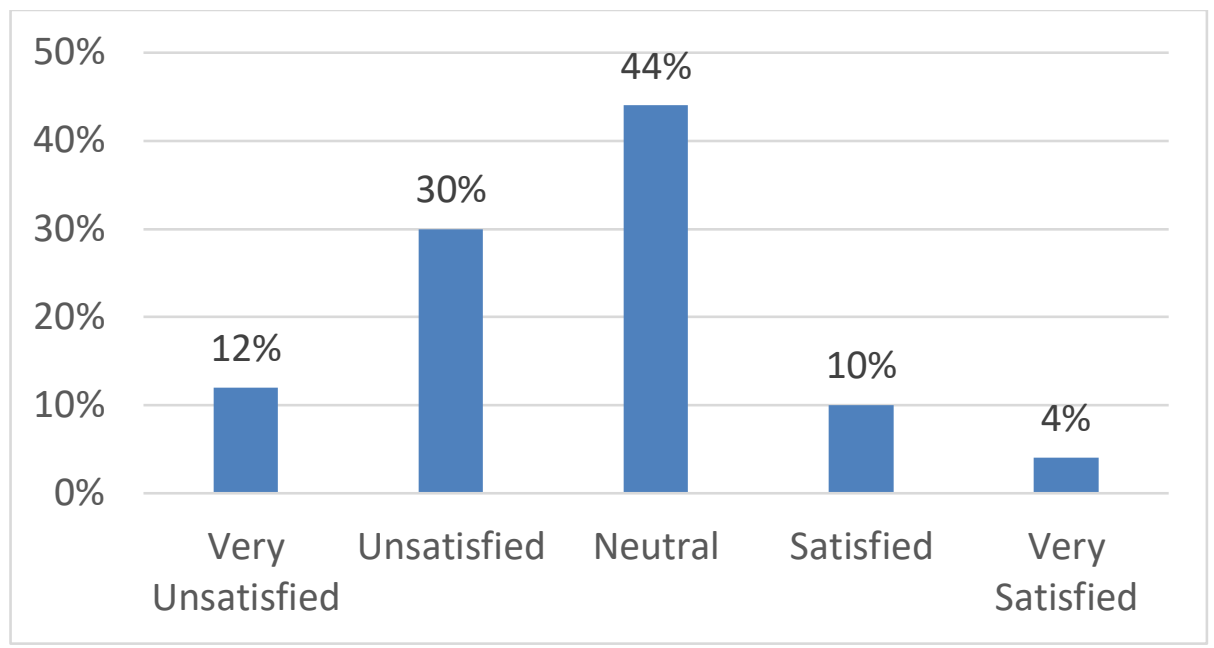

Source: Authors, 2020

Image 1: Newspaper Coverage Regarding Lack of Urban Basic Services in the Study Area

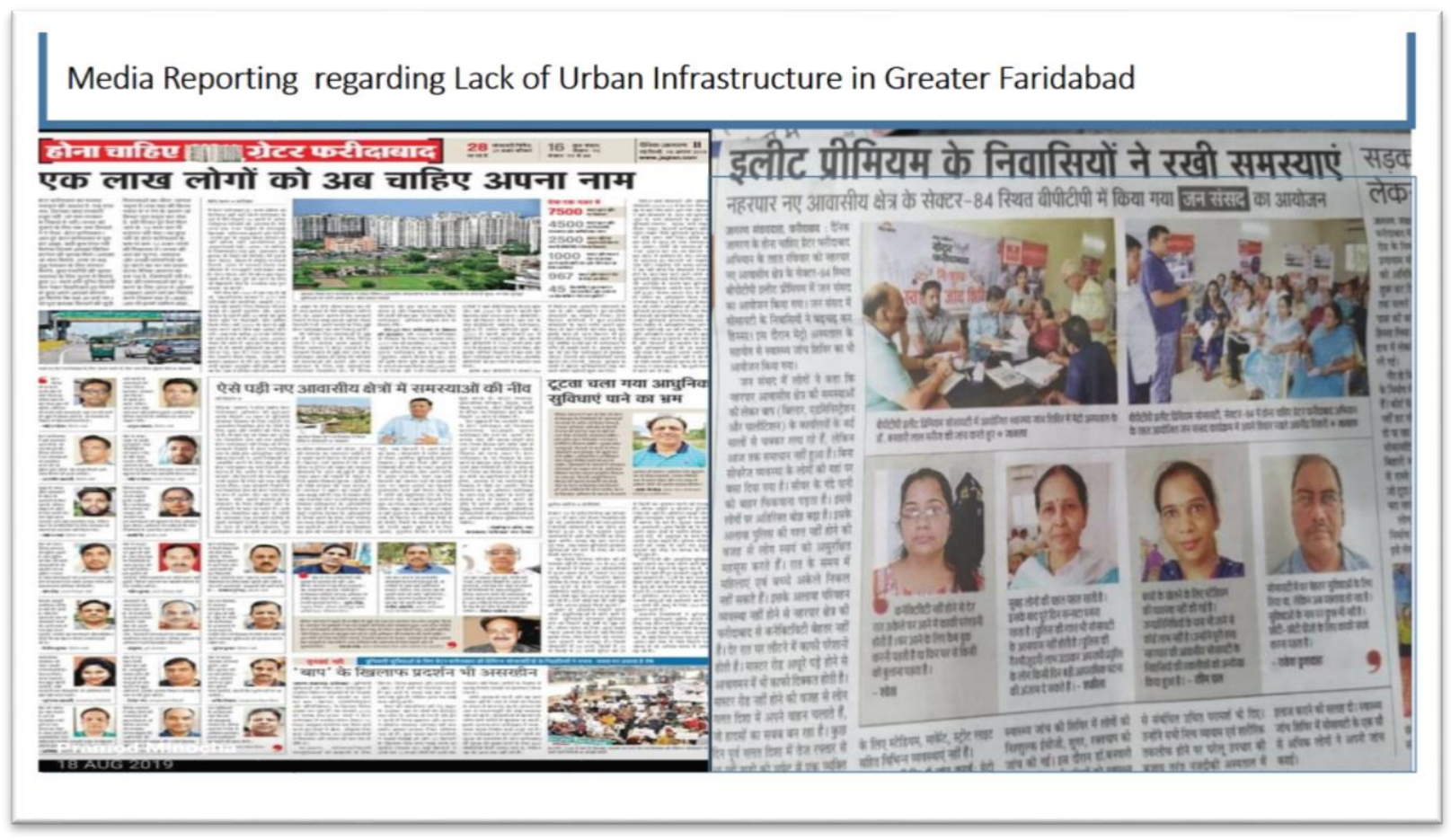

Source: Dainik Jagran, Hindi Newspaper, 2019 


\subsubsection{Satisfaction level regarding access to road near society}

\section{Satisfaction level and Access to Road near Society}

The lack of access to road near residential gated societies is an important urbanisation challenge which require much attention. Investing in essential infrastructure propels growth and human development (ThangavelPalanivel, September 2017). According to Jaspal Singh(14 December, 2016), who is also an Urban Transport Expert, it is believed that in India, the physical infrastructure hasn't been able to keep pace with the growth in demand. The urban road length has increased from $252,001 \mathrm{~km}$ in 2001 to $411,840 \mathrm{~km}$ by 2011 . In the last decade registered vehicles per million populations has increased by $219 \%$ while urban road infrastructure per million only increased by $124 \%$. Hence lack of access to road is major problem and also impacts the wellbeing of the people.

In the survey conducted, 16 of $50(32 \%)$ respondents had a neutral opinion on access to roads near their society. Notably, 10 (20\%) were unsatisfied. At the same time, $16(32 \%)$ were satisfied and $8(16 \%)$ very satisfied. The full distribution of responses has been presented in the following graph.

\section{Graph 2: Satisfaction level and Access to Road near Society}

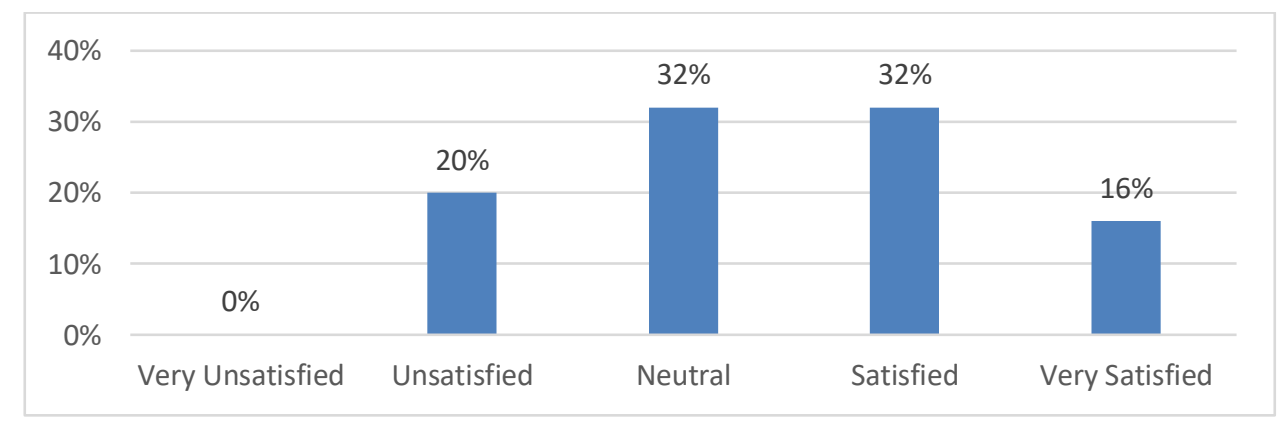

Source: Authors, 2020 
International Journal of Social Science and Economic Research

ISSN: 2455-8834

Volume:06, Issue:02 "February 2021"

Image 2: Newspaper Coverage Regarding No Road or Insufficient Road in the Study Area

Newspaper and Social Media Coverage Regarding Lack of Road in Greater Faridabad Gated Societies
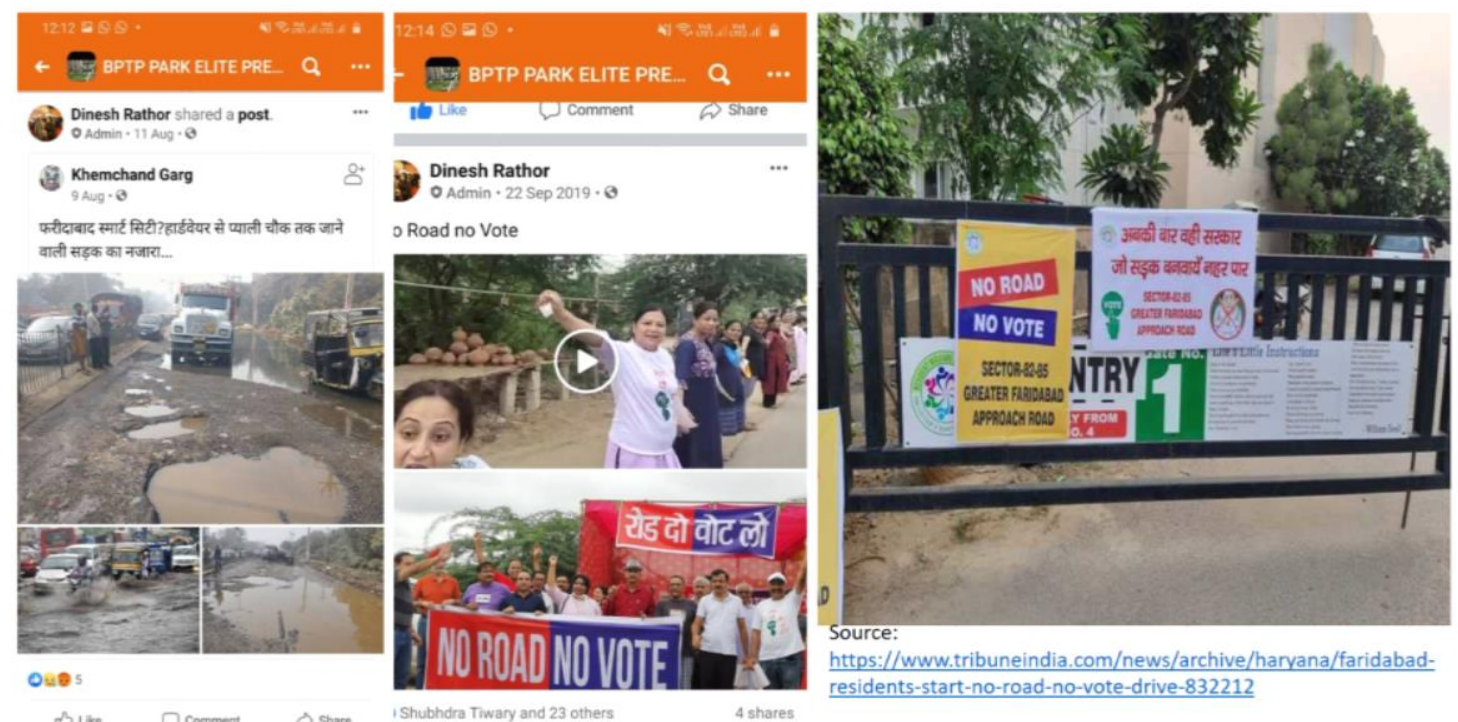

Source: BPTP Park Elite Premium RWA Facebook Homepage

\subsubsection{Satisfaction level and Sewer Disposal of the Society}

An estimated 62,000 million litres per day (MLD) sewage is generated in urban areas, while the treatment capacity across India is only 23,277 MLD, or $37 \%$ of sewage generated, according to data released by the government in December 2015. Further parsing of this data reveals that of 816 municipal sewage treatment plants (STPs) listed across India, 522 work. So, of 62,000 MLD, the listed capacity is 23,277 MLD but no more than 18,883 MLD of sewage is actually treated. That means $70 \%$ of sewage generated in urban India is not treated (Chaitanya Mallapur, 27 Jan, 2016).

In the survey 15 of the 50 respondents (30\%) were very unsatisfied with the sewer disposal. Another 10 (20\%) were unsatisfied. The full distribution of responses has been presented in the following graph. 
International Journal of Social Science and Economic Research

ISSN: 2455-8834

Volume:06, Issue:02 "February 2021"

\section{Graph 3: Satisfaction level and Sewer Disposal of the Society}

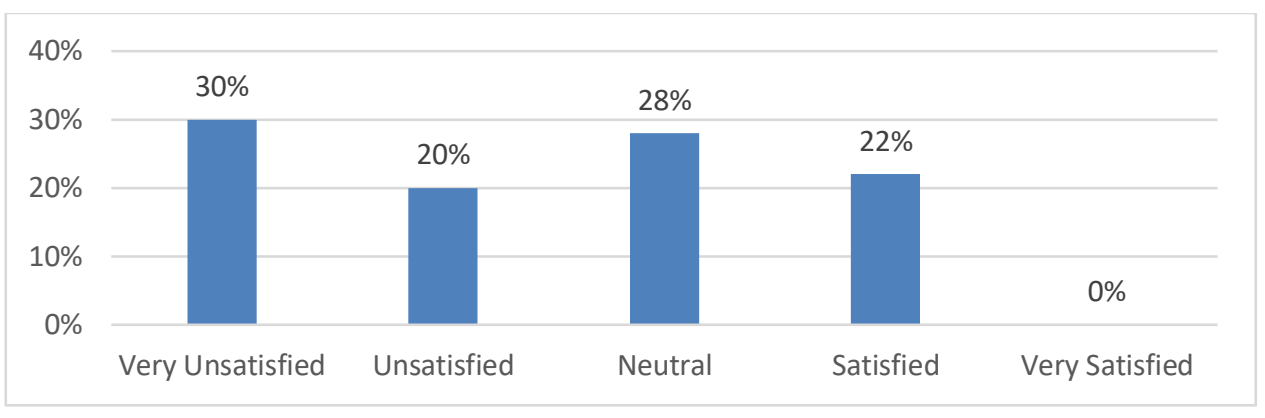

Source: Authors, 2020

\section{Image 3: Newspaper Coverage Regarding Lack of Sewer Disposal in the Study Area}

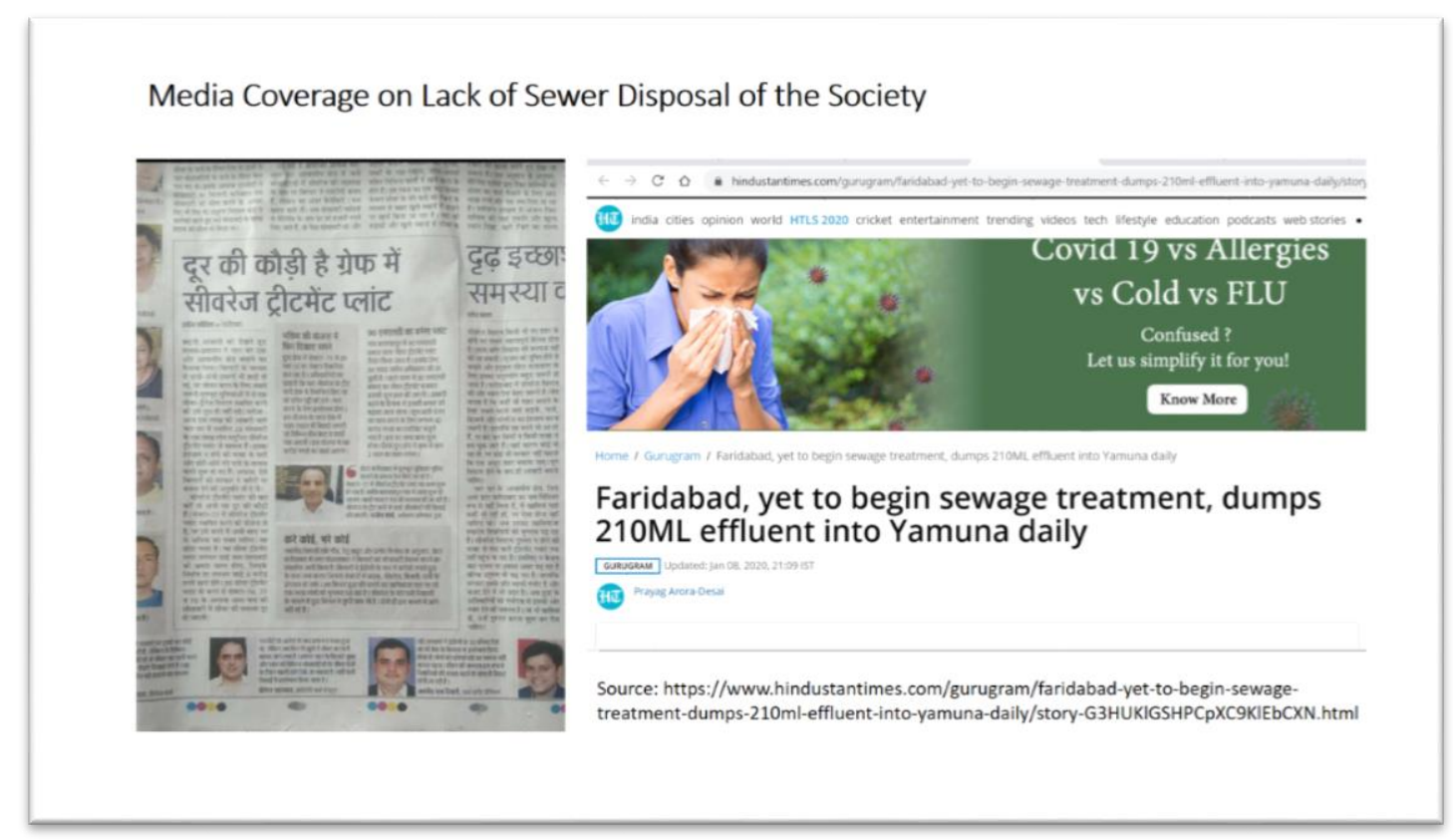

Source: DainikJagran, Hindi Newspaper, 2 Feb 2019

\subsubsection{Satisfaction Level and Power backup (DG) Cost}

Prayag Arora-Desai (Hindustan Times, Oct 09, 2019) stated that there is an over reliance on DG sets in Gurugram, Faridabad, Noida in the absence of proper power supply Grid lines which is a logistical challenge. It is also evident from the survey. In the study area when respondents were asked about overreliance on DG Set, following responses emerged from the survey, where 16 of the 50 respondents $(32 \%)$ were very unsatisfied with the cost of power back up. Another 12 
International Journal of Social Science and Economic Research

ISSN: 2455-8834

Volume:06, Issue:02 "February 2021"

(24\%) were unsatisfied. The full distribution of responses has been presented in the following graph.

Graph 4: Satisfaction Level and Power backup (DG)

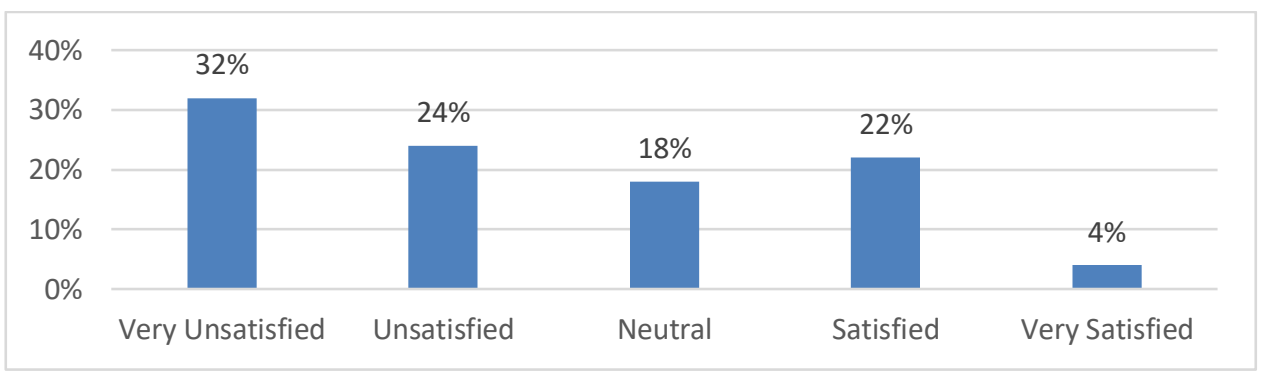

Source: Authors, 2020

Image 4: Newspaper Coverage Regarding Over Reliance on DG Sets in the Study Area
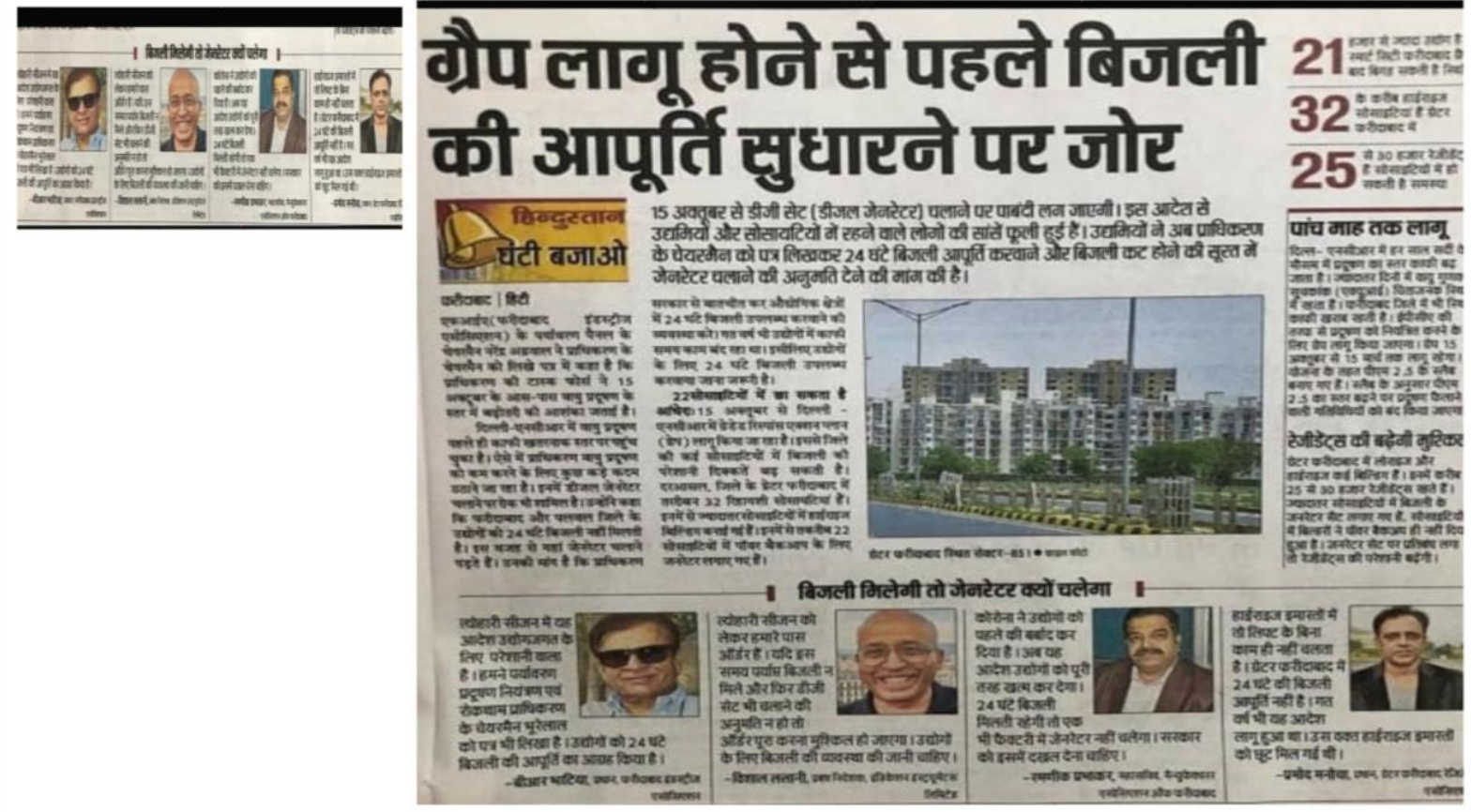

Source: Hindustan Newspaper, Hindi Newspaper, 2019

\subsubsection{Satisfaction Level and Infrastructure within society}

Infrastructure can impact human lives tremendously. Adequate infrastructure and services serve as a backbone for growth and are essential for community health, safety, and quality of life 
(Humboldt County General Plan, 2007). It also influences resident's overall satisfaction level. So it can be stated that when infrastructure within society is good, it greatly influences residents' satisfaction level.

In the survey conducted in the study area, 22 of the 50 respondents (44\%) had a neutral opinion on the infrastructure within their society.17 (34\%) were satisfied with the it. The full distribution of responses has been presented in the following graph.

\section{Graph 5: Satisfaction Level and Infrastructure within society}

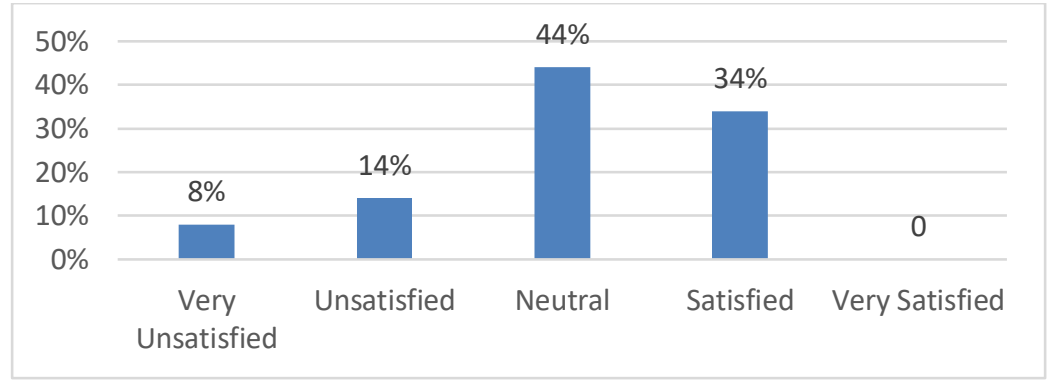

Source: Authors, 2020

\subsubsection{Satisfaction Level and the Security System of the society}

The demand for housing located within metropolitan areas (not rural), but outside the central cities (not core), also raised concern over safety and crime issues. Although gated residential socities are perceived as safe spaces because of the presence of CCTVs, security guards etc. However, despite the presence of added security, in the survey it was found that 21 of the 50 respondents $(42 \%)$ had a neutral opinion on the security system within their society.16 (32\%) were satisfied with the it. The full distribution of responses has been presented in the following graph.

\section{Graph 6: Satisfaction Level and the Security System of the society}

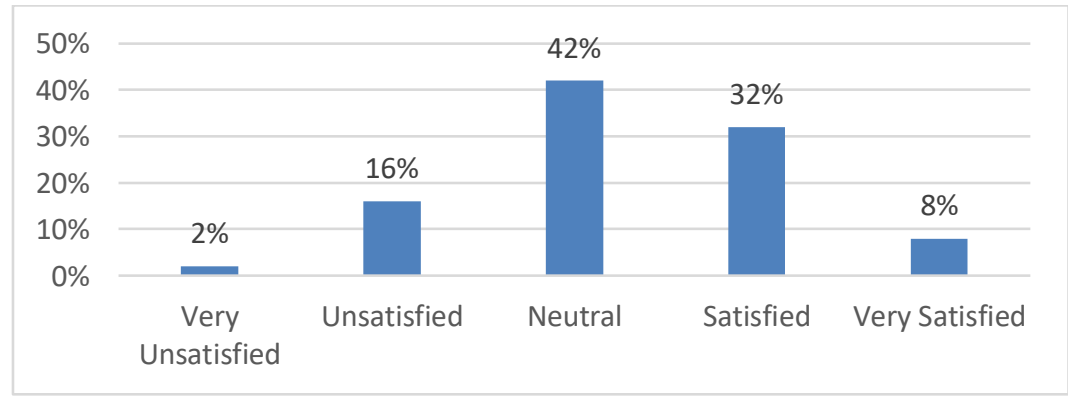

Source: Authors, 2020 


\subsubsection{Satisfaction Level with Respondents' Neighbourhood}

The good neighbourhood enhances the quality of life and is greatly influenced by improved safety of residents, hygienic environment, aesthetics etc. In the survey a majority of the respondents were either satisfied (26 or 52\%) or very satisfied (8 or 16\%) with the neighbourhood within their society. The full distribution of responses has been presented in the following graph.

\section{Graph 7: Satisfaction Level with Respondents' Neighbourhood}

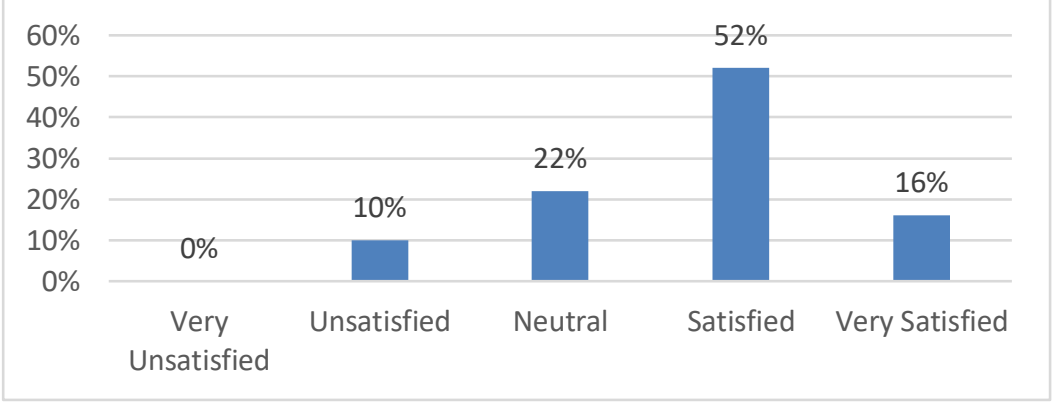

Source: Authors, 2020

\subsubsection{Family/Friend Network in Greater Faridabad}

Place attachment is the cognitive-emotional bond that forms between individuals and their important settings, is a common human experience with implications for their well-being (Leila Scannell, Robert Gifford, 2017). The people feel connected and socially integrated in the study area. In the primary survey 40 out of $50(80 \%)$ of the respondents stated that they had family/friend network in the gated residential societies they live in Greater Faridabad. Having friends and socially integrated makes people more attached to the place.

\subsubsection{Liking and Place Attachment}

Place attachment is influenced by a number of factors and usually research in this area integrates the perceptual, psychological, physical, and the socio-cultural dimensions of people and place (Mina Najafi and Mustafa Kamal M. S, 2012). One cannot take place attachment alone. Kenny Chow and Mick Healey(Dec 2008) in their study, stated that peoples' place liking is also influenced by the fact that if the people have moved to the place from the similar kind of places are more attached to the place. Place attachment contributes to the wellbeing of the people as well (MrittikaBasu, Shizuka Hashimoto \&RajarshiDasgupta ,2019). 
In the survey conducted, when asked, "if they liked their locality?" majority of the respondents said that they like the place they live in (92\%) as well as they are attached to the place they live in $(84 \%)$. It is evident from the graph given below:

In the discussion it was found that some of the residents have bought flats post retirement, some have moved from the very big cities to this place. People coming from bigger towns or are foreign returns like the place but are not satisfied with the urban infrastructure. Many of them have very high mobility and are at different stages of their lives.

These findings support the argument that place attachment is greatly influenced by the extent individual feel integrated in the neighbourhood and also impacts wellbeing.

\section{Graph 8: Liking and Place Attachment}

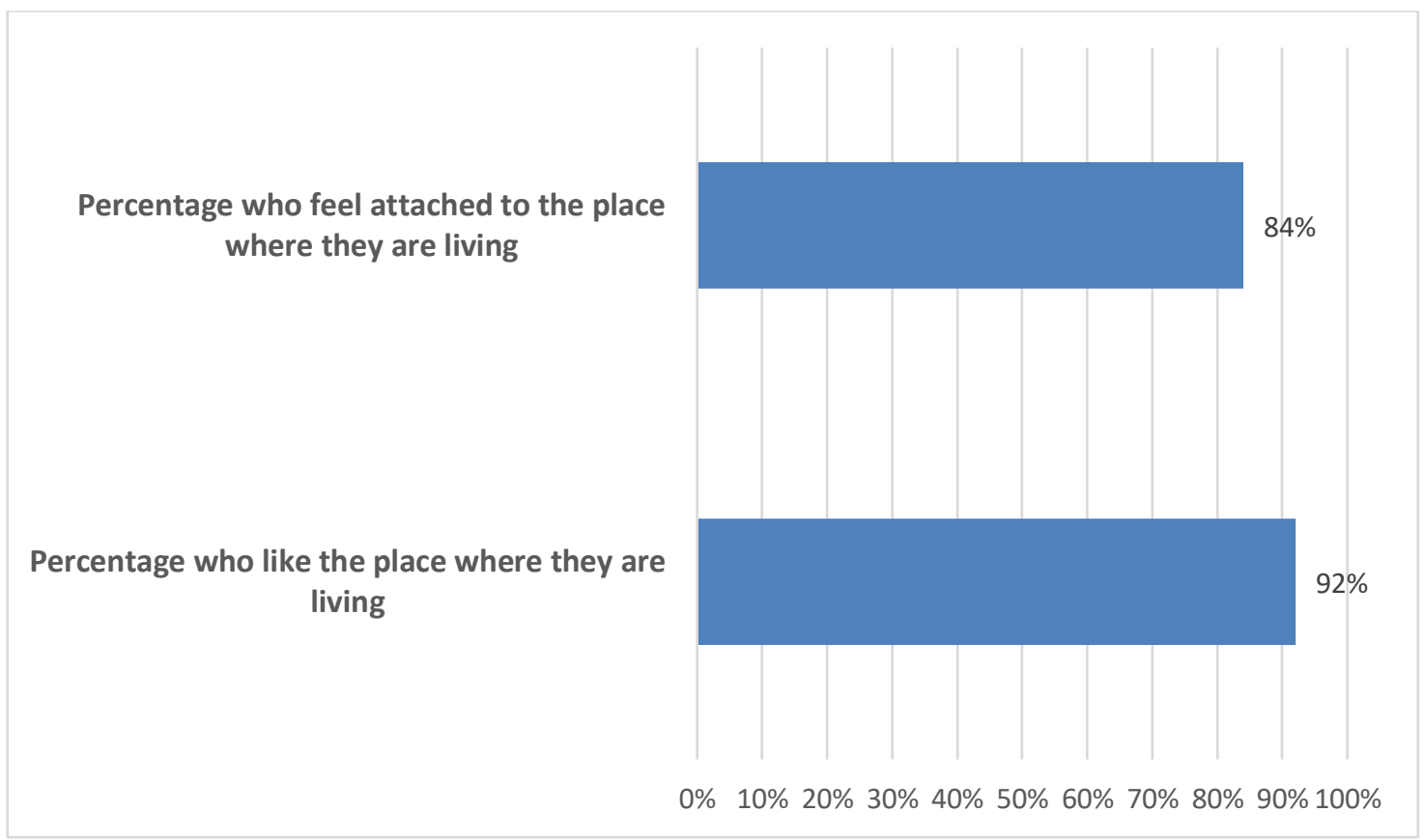

Source: Authors, 2020 
Image 5: Gated Societies of Greater Faridabad and Internal Infrastructure

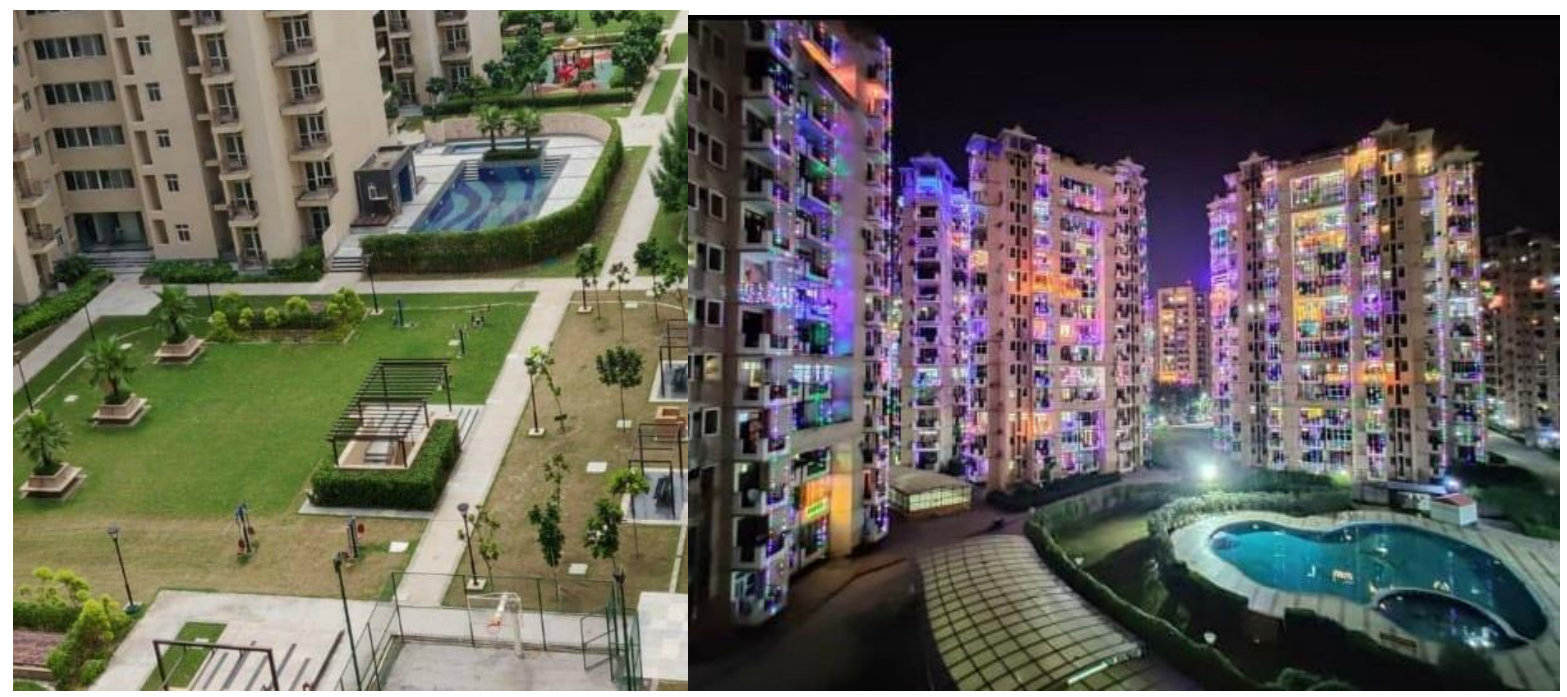

Source: Authors, 2020

\subsubsection{Statistical Modelling / Test of Place Attachment}

The results of the simple logistic regressions with Place Attachment as the dependent variable, and variables related to urban infrastructure and amenities, infrastructure and amenities within gated societies, family/friend network in Greater Faridabad etc. as independent variables have been presented in the following table.

Table 1: Statistical Modelling/ Test of Place Attachment - Logistic Regrssions and Chi Square Tests

\begin{tabular}{|l|l|l|l|l|l|}
\hline $\begin{array}{l}\text { Model } \\
\text { No. }\end{array}$ & $\begin{array}{l}\text { Independent } \\
\text { Variable }\end{array}$ & $\begin{array}{l}\text { Nature } \\
\text { Variable }\end{array}$ & $\begin{array}{l}\text { Model } \\
\text { Chi } \\
\text { Square }\end{array}$ & $\begin{array}{l}\text { P Value of } \\
\text { Chi } \\
\text { Square }\end{array}$ & $\begin{array}{l}\text { Significance } \\
\text { of } \\
\text { Association }\end{array}$ \\
\hline 1 & $\begin{array}{l}\text { Satisfaction level } \\
\text { with } \\
\text { infrastructure quality } \\
\text { in Greater Faridabad }\end{array}$ & $\begin{array}{l}\text { Unsatisfied to } \\
\text { Very Satisfied } \\
\text { Very }\end{array}$ & 0.21 & 0.65 & $\begin{array}{l}\text { Not } \\
\text { Significant }\end{array}$ \\
\hline
\end{tabular}


International Journal of Social Science and Economic Research

ISSN: 2455-8834

Volume:06, Issue:02 "February 2021"

\begin{tabular}{|c|c|c|c|c|c|}
\hline 2 & $\begin{array}{l}\text { Satisfaction level } \\
\text { regarding access to } \\
\text { road near your } \\
\text { society }\end{array}$ & $\begin{array}{l}5 \text { Point Scale - } \\
\text { Very } \\
\text { Unsatisfied to } \\
\text { Very Satisfied }\end{array}$ & $5.04 *$ & $0.025^{*}$ & Significant \\
\hline 3 & $\begin{array}{l}\text { Satisfaction level } \\
\text { with sewer disposal } \\
\text { in your society }\end{array}$ & $\begin{array}{l}5 \text { Point Scale - } \\
\text { Very } \\
\text { Unsatisfied to } \\
\text { Very Satisfied }\end{array}$ & 0.02 & 0.9 & $\begin{array}{l}\text { Not } \\
\text { Significant }\end{array}$ \\
\hline 4 & $\begin{array}{l}\text { Satisfaction level } \\
\text { with cost of Power } \\
\text { backup (DG) }\end{array}$ & $\begin{array}{l}5 \text { Point Scale - } \\
\text { Very } \\
\text { Unsatisfied to } \\
\text { Very Satisfied }\end{array}$ & 1.13 & 0.29 & $\begin{array}{l}\text { Not } \\
\text { Significant }\end{array}$ \\
\hline 5 & $\begin{array}{lr}\text { Your satisfaction } \\
\text { level } & \text { about } \\
\text { infrastructure } & \text { within } \\
\text { your society? } & \end{array}$ & $\begin{array}{l}5 \text { Point Scale - } \\
\text { Very } \\
\text { Unsatisfied to } \\
\text { Very Satisfied }\end{array}$ & 1.93 & 0.16 & $\begin{array}{l}\text { Not } \\
\text { Significant }\end{array}$ \\
\hline 6 & $\begin{array}{l}\text { Are you satisfied } \\
\text { with the security } \\
\text { system you get in the } \\
\text { society? }\end{array}$ & $\begin{array}{l}5 \text { Point Scale - } \\
\text { Very } \\
\text { Unsatisfied to } \\
\text { Very Satisfied }\end{array}$ & 0.01 & 0.92 & $\begin{array}{l}\text { Not } \\
\text { Significant }\end{array}$ \\
\hline 7 & $\begin{array}{l}\text { How satisfied you are } \\
\text { with your } \\
\text { neighbourhood? }\end{array}$ & $\begin{array}{l}5 \text { Point Scale - } \\
\text { Very } \\
\text { Unsatisfied to } \\
\text { Very Satisfied }\end{array}$ & 0.75 & 0.39 & $\begin{array}{l}\text { Not } \\
\text { Significant }\end{array}$ \\
\hline 8 & $\begin{array}{l}\text { Friends/Family } \\
\text { Network in Greater }\end{array}$ & $\begin{array}{l}\text { Significant } \\
\text { Yes/No }\end{array}$ & $4.5^{*}$ & $0.034 *$ & Significant \\
\hline
\end{tabular}


International Journal of Social Science and Economic Research

ISSN: 2455-8834

Volume:06, Issue:02 "February 2021"

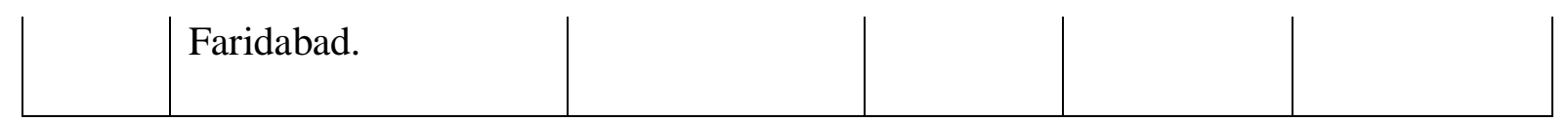

* significant at the $95 \%$ level of confidence

Source: Based on Survey Result Analysis, 2020

A significant value indicates that one or more of the independent variables have a significant effect but does not indicate which independent variable. Since, each of the simple logistic regression models presented above has only one independent variable, it can be inferred that the significance of the model is on account of that independent variable.

\subsubsection{Inference from the Model}

From the above study, we can infer that, there is significant association between place attachment and access to road as well as "place attachment" and "friends/family network in Greater Faridabad" in the sample. The association with other aspects of urban infrastructure and amenities does not appear to be significant.

In general, better delivery of infrastructure like access to road, sewer disposal, power backup, security system within residential society etc. poses a great challenge for these residential societies.

Urban basic service delivery is strongly related with wellbeing of the people but here in the selected sample is not the determining factor for the place attachment. Rather in the study area place attachment is more influenced by infrastructure within gated residential society and friends and likeminded people within the society. People with higher place attachment report greater social and political involvement in their communities (Mesch\& Manor, 1998). It also promotes overall wellbeing as attaining wellbeing in life is the main objective of life for any individual.

\section{Conclusions}

The present paper provides an evidence-based case study which suggest that notion of place attachment depends on social and local interpersonal bonds, especially within gated societies and is less affected by Urban basic infrastructure inaccessibility, although this causes feeling of dissatisfaction.

People have different ways to get related to the place.In the present study many of the residents have their work place in Delhi. So for them it is easier to live in the Greater Faridabad gated societies with good security, road connectivity and decongested place, unlike many places of Delhi. So the characteristics of the value derived by those who have moved from Delhi to Faridabad is totally different from people who have shifted to this place from smaller towns. And 
International Journal of Social Science and Economic Research

ISSN: 2455-8834

Volume:06, Issue:02 "February 2021"

their reason for place attachment, would appear that, basically everything is available within the gated society despite the fact that they are not satisfied with urban infrastructure development in this area.

The present study also suggests that all residents are strongly in favour of development of urban infrastructure, although it may not necessarily have a bearing on their place attachment. Greater Faridabad by transforming its infrastructure can become more liveable city.

Acknowledgment: The Authors express their heartfelt gratitude to the RWA Members for giving their valuable time and assisting in the field work.

\section{References}

AkashVashistha (September 07, 2007). Flourishing Faridabad. The Economic Times, (Online Web) Accessed on 18 December, 2020. https://economictimes.indiatimes.com/etrealty/flourishing-faridabad/articleshow/2345921.cms?from=mdr.

Altman and Low (1992). "Place Attachment: A Conceptual Inquiry", Human Behaviour and Environment, Vol. 12, Springer, pp. 1-12.

Ashwini M Sripad, (27th December 2017). Satellite Towns Can Unclog Big Cities, Express News Service. (Online Web) Accessed on 22 November 2020. Https://Www.Newindianexpress.Com/States/Karnataka/2017/Dec/27/Satellite-TownsCan-Unclog-Big-Cities-1737668.Html.

BijendraAhlawat, (Sep 14, 2019). Faridabad Residents Start 'No Road, No Vote' Drive. Tribune News Services. (Online Web). Accessed on $15^{\text {th }}$ Dec 2020. Https://Www.Tribuneindia.Com/News/Archive/Haryana/Faridabad-Residents-Start-NoRoad-No-Vote-Drive-832212.

Chaitanya Mallapur. (27 Jan, 2016). 70\% Of Urban India's Sewage Is Untreated. India Spend. (Online Web) Accessed on 23 December 2020. https://www.indiaspend.com/70-ofurban-indias-sewage-is-untreated-54844/.

Dan Plunkett,Rhonda Phillips \&BelginUcarKocaoglu (2018). Place Attachment and Community Development. Journal of Community Practice Volume 26, 2018 - Issue 4. https://doi.org/10.1080/10705422.2018.1521352.

Department of Town and Country Planning, Haryana Government (July 2014). Faridabad Master Plan, 2031. (Online Web) Accessed 15 ${ }^{\text {th }}$ May 2018, URL: https://tcpharyana.gov.in/. 


\section{International Journal of Social Science and Economic Research}

ISSN: 2455-8834

Volume:06, Issue:02 "February 2021"

Humboldt County General Plan. (2007). Community Infrastructure and Services Element.(pp. 71 - 7-64), Retrieved from http://www.humboldtgov.org/DocumentCenter/View/2096, Last Accessed July 7, 2017.

IshaBhatnagar. (March, 2017). Do We Need Smart Or Wise Cities? Infrastructure Today. (Online Web) Accessed on $1^{\text {st }}$ December 2020, Https://Infrastructuretoday.Co.In/Special-Feature/Do-We-Need-Smart-Or-Wise-Cities$\underline{106413 .}$.

Jaspal Singh. (14 December, 2016). City public transportation developments in India.Intelligent Transport. (Online Web) Accessed on 23rd December 2020.https://www.intelligenttransport.com/transport-articles/21458/city-publictransportation-india/

Kenny Chow, Mick Healey. Dec 2008. Place Attachment and Place Identity: First-Year Undergraduates Making the Transition from Home to University. Journal of Environment Psychology. 28(4):362-372. DOI: 10.1016/j.jenvp.2008.02.011

Leila Scannell, Robert Gifford (2017). The experienced psychological benefits of place attachment. Journal of Environmental Psychology 51(2017)256-269.

Mesch, G. S., \& Manor, O. (1998). Social ties, environmental perception, and local attachment. Environment and Behavior, 30, 504e519.

Mina Najafi and Mustafa Kamal M. S, 2012. The concept of place attachment in environmental psychology. Sustainable Architecture. / Elixir Sustain. Arc. 45 (2012) 7637-7641.

MrittikaBasu, Shizuka Hashimoto \&RajarshiDasgupta (2019). The mediating role of place attachment between nature connectedness and human well-being: perspectives from Japan. Sustainability Science volume 15, pages849-862.

Noga Collins-Kreiner (2020). Special Issue "Place Attachment in the Age of Globalization, Digitalization and Virtual Reality. Sustainability 12(11), 4548; https://doi.org/10.3390/su12114548.

Prayag Arora-Desai (Oct 09, 2019). Use of diesel generators to be banned around NCR from Oct 15. Hindustan Times. (Online Web) Accessed on 23 December 2020. https://www.hindustantimes.com/cities/diesel-generators-to-be-banned-from-october-15in-gurugram/story-FiTLE1M7Chh85gk3ogolwO.html.

R. A. Ogunbajo, M. O. Bello and M. A. Adebayo (June, 2016). Assessment of Urban Infrastructure Quality and User Satisfaction in Low Income Residential Neighbourhoods 
International Journal of Social Science and Economic Research

ISSN: 2455-8834

Volume:06, Issue:02 "February 2021"

in Minna, Nigeria. ATBU Journal of Environmental Technology 9, 1, print ISSN: 15966035 .

Relph (1976), Place and Placelessness. London: Pion.

Roitman.(March 2010). Design And Planning 163 Issue Dp1, Issue Dp1, Proceedings Of The Institution OfcivilEngineersurbans. Pages 31-38 doi: 10.1680/Udap.2010.163 .1.31.

SamerBagaeen, Ola Uduku. 2010. Gated Communities: Social Sustainability In Contemporary And Historical Gated Developments. Published December 7, 2012 By Routledge. Isbn 9780415830416.

Soroush Karami1, MojganGhafary, Abbas Fakhrayee. (2014). Analyzing the correlation between urban spaces and place attachment Evidence from: Narmakneighborhood in Tehran. European Online Journal of Natural and Social Sciences. Vol.3, No.4 Special Issue on Architecture, Urbanism, and Civil Engineering. ISSN 1805-3602.

ThangavelPalanivel (06 September 2017). Rapid urbanisation: opportunities and challenges to improve the well-being of societies. Human Development Report Office, UNDP. (Online Web) Accessed on 23 Dec 2020. http://hdr.undp.org/en/content/rapid-urbanisationopportunities-and-challenges-improve-well-being-societies.

The Hindu. (August 22, 2014). Suburban Problems. The Hindu. (Online Web) Accessed on August 21, 2020. Https://Www.Thehindu.Com/Features/Homes-And-Gardens/SatelliteTownships-Suburban-Problems/Article6342761.Ece. 